\title{
Mediated Representations of Violence Against Women
}

Viktorija Car

University of Zagreb (Croatia)

\section{Barbara Ravbar}

University of Zagreb (Croatia)

Violence against women and girls in the $21^{\text {st }}$ century remains a common and profoundly consequential violation of women's human rights. It is part of gender inequality, an integral part of the social system, and linked to other aspects of human and economic development. When reporting about it, the media produce additional damage by continuously highlighting the hostile and violent treatment of women. Representations of gender and sexuality in the news reinforce the common perception that women are sexual objects and therefore disadvantage women, continuously reinforcing imbalances of power between women and men. This study explores media representations in Croatian online media articles about violence against women. The results of analysis show how violence against women is framed as a private problem, how women are addressed as unfaithful wives and prostitutes which gives excuses for the perpetrator while the blame for the violence is partly shifted to the woman. Also, results show how the secondary victimization is manifested in articles, and how violence against women as a topic is exploited to attract the readers' attention.

Keywords: violence against women, journalistic reporting, media frames, Croatia.

$\mathrm{D}$ espite significant accomplishments in gender equality over the past decades, violence against women and girls remains common and profoundly consequential violation of women's human rights. It is part of gender inequality, an integral part of the social system, and linked to other aspects of human and economic development (Walby, 2005: 2).

The role of the media in promoting gender equality is an unavoidable factor in the development of democratic societies. Media have an especially important role in challenging gender stereotypes and bad custom of representing women as 
victims when reporting on gender-based violence. Media practices continuously perpetuate and impose gender stereotypes, attributing strength characteristics and abilities to men while weak characteristics to women (Hermes, 2012: 14). Such practices reflect power relations. Representations of gender and sexuality in news and entertainment forms "tend to reinforce sexual difference and imbalances of power" in ways that disadvantage women (Carter, Steiner, and McLaughlin, 2013: 3). Academic studies confirm that the media in different forms, from news to fiction, continuously highlight the hostile and violent treatment of women (Cuklanz, 2013: 32). The mediated representation of gendered power (Banks, 2018: 157) has a direct effect on sympathetic or other kind of audience response (Carlyle et al., 2014).

Media representations which link masculinity and violence, and femininity and victimization, have been continuously studied and discussed in academic society since the 1970s (Mulvey 1975; Haskell, 1974; Tuchman, 1978). Media constructions of masculine identity are widely articulated with violence, power, and control, while women are objectified in the media since the focus is on presentation of the female body. Laura Mulvey (1975) argues that visual culture in patriarchy is structured with a "male gaze" that tends to objectify the female body and present the woman as a passive subject. According to objectification theory, the primary psychological consequence of sexual objectification is the development of unnatural perspectives on oneself which is called self-objectification (Calogero, 2004: 16). Additionally, the normalization of pornographic representations in mainstream media and mainstream culture reinforces the common perception that women are sexual objects (Carter, Steiner, and McLaughlin, 2013: 2). Further damage the media do is positioning sexually assaulted women as somehow "being out of line" or "to blame for such violence precisely because they have asserted their sexual agency". (Ibidem) Even in nonfiction media formats, like news, it is common that journalists tend to portray women or as victims, or those who deserved to be punished (Cullen, O'Brien, and Corcoran, 2019).

\section{JOURNALISTIC REPORTING ON VIOLENCE AGAINST WOMEN}

The news is a vital component of the life of individuals, groups, communities, and nations. Whether it is written or visual, the news represents the world, and it represents it as "reality". However, media affect the news they carry, and they frame reality. Media frames are generally seen as coherent packages of information containing "a central organizing idea or story line that provides meaning to an unfolding strip of events" (Gamson and Modigliani, 1987: 143). Through framing, or deciding to include or exclude contents and people, media construct the picture of reality and of everyday life. On the other hand, because of its mass influence, media helps preserving old or creating new social values. The media thus construct a different, in a way, "ideological reality" (Lewis, 1991) in which they understand the binary relationship between "us and them", understand who is "good" and who is "bad". 
In the process of creating a media image of society and reality, journalists, and editors, as well as other media professionals involved in the process of creating media content (graphic editors, photojournalists, cameramen, sound technicians, web designers, producers, etc.), make their choices (Car and Osmančević, 2016). All of them are directly involved in the process of constructing an image of what they are reporting about. The media thus represent influential critics and agents in contemporary processes of constructing knowledge (Hay and Israel, 2001: 108).

The focus of this paper is on how journalists construct news about the violence against women, and it is not on audience interpretation of news. How the media audience will understand and interpret the news depends on their knowledge, motivation, and abilities, but also on the context in which the news is watched or read. The process of deriving meaning from media representation is limited by social conventions, community experiences, and social context that limit the range of possible meanings in each situation (Car, 2015: 9).

Research on media representations of violence against women confirms that news reports frequently mirror societal constructions and ambivalence about this issue (Morgan and Politoff, 2012). In media coverage on violence against women there are five common elements: omission of social context, sensationalism, misrepresentation, victim blaming, and the erasure of victim's voices (Sutherland et al., 2016). UNESCO's handbook for journalists (Impe, 2019) discusses the reflections, recommendations, and good practices common to the coverage of violence against women and girls. Authors recommend which words, language, images, or titles should be chosen, how should an article on gendered violence be framed and how a journalist should talk to a survivor. Among 15 general recommendations we have selected seven we found most suitable for analysis.

1. The first and the most important recommendation is to start talking about violence against women. Just to address gender-based violence as an important social issue is already an important contribution, because keeping silent endorses the idea that these are minor acts or an insignificant phenomenon. Still, the opposite trend of exaggeration, complacency, and voyeurism about violence against women is not professional journalistic approach, and should be avoided (Impe, 2019: 109).

2. Gender-based violence should be treated as a violation of human rights and no longer as an isolated incident. Usually, such violations are presented in media as individual, private stories of events which happened within the family, but "violence against women is a systemic attack, resulting from power relationships and domination that affects society as a whole" (Impe, 2019: 110).

3. Explaining the context ensures that journalists provide keys to understanding the phenomenon of violence through statistical data, putting events in perspective and an explanation of its systemic nature.

4. Journalists should be careful with vocabulary, especially using words which seem to question the victim's word or role in the violent act.

5. Journalists should reject language that 'lectures' or that could incite judgment. 
6. It is important to avoid sensationalism, so editors should pay attention to headings. Headlines attract the reader more than the content and in the context of social media, shared links are sometimes not even opened, but are still shared and passed on just because of an attractive headline (Impe, 2019: 113).

7. It is important to describe reality while avoiding sensationalism.

There are more academic and professional reports focused on this issue. International Federation of Journalists (IFJ) published a list of ten main Guidelines for Reporting on Violence Against Women (IFJ, 2014: 1-2) emphasizing how important is the report to be accurate, non-judgmental, avoiding victimization and sensationalism. Any framing of this issue brings with it inclusions and exclusions. According to Yates (2020: 5) "'women-centred' framing acknowledges that women are disproportionately affected" and it is important if a woman will be portrayed as a 'victim' or as a 'survivor'. According to Berns (2004: 84) framing a woman as a victim is common in "sensational and titillating articles".

\section{RESEARCH FRAMEWORK AND METHODS}

The objective of this study is to identify framing in representing women in Croatian online media articles while reporting about violence against women. We especially focused on articles which represent a woman as a victim, emphasizing her responsibility for being raped or beaten, or abused in any other way. There are five research questions we want to answer:

- RQ1: How is violence against women framed in selected articles?

- RQ2: How are women addressed in selected articles?

- RQ3: Through which narratives the blame has been shifted from the perpetrator to survivor?

- RQ4: How secondary victimization of a woman has been manifested in the article?

- RQ5: How violence against women as a topic is exploited to attract the reader's attention, through headings and through sensationalism?

In this qualitative media text analysis, we used three research methods: framing analysis, narrative analysis, and critical discourse analysis. Framing analysis is an approach to analysing news with focus on how public discourse about certain issue is constructed (Pan and Kosicki, 1993: 70). The concept of news framing refers to an interpretative frame, a cognitive system emanating from a journalist's or an editor's consciousness, that helps in the process of news selection and news coverage (Kunczik and Zipfel, 1998: 103). Framing analysis suggests: 
Narrative analysis focuses on latent structures and significant elements that structure meaning of news and position the reader (Gillespie, 2006). It focuses on how the news story is structured (the beginning, the middle, and the end) and narrated (Car and Osmančević, 2016). Critical discourse analysis is an analysis of the language. It seeks to explore on the one hand, the ways in which a particular discourse, in our case news discourse, is shaped by power relations and domination in society, and on the other hand the ways in which discourse itself plays an active role in building or destroying those relationships (Fairclough, 2010; Dijk, 2001; Wodak and Busch, 2004).

\section{Graph 1. Articles published under hashtags 'violence against women' and 'he has beaten up a woman'}

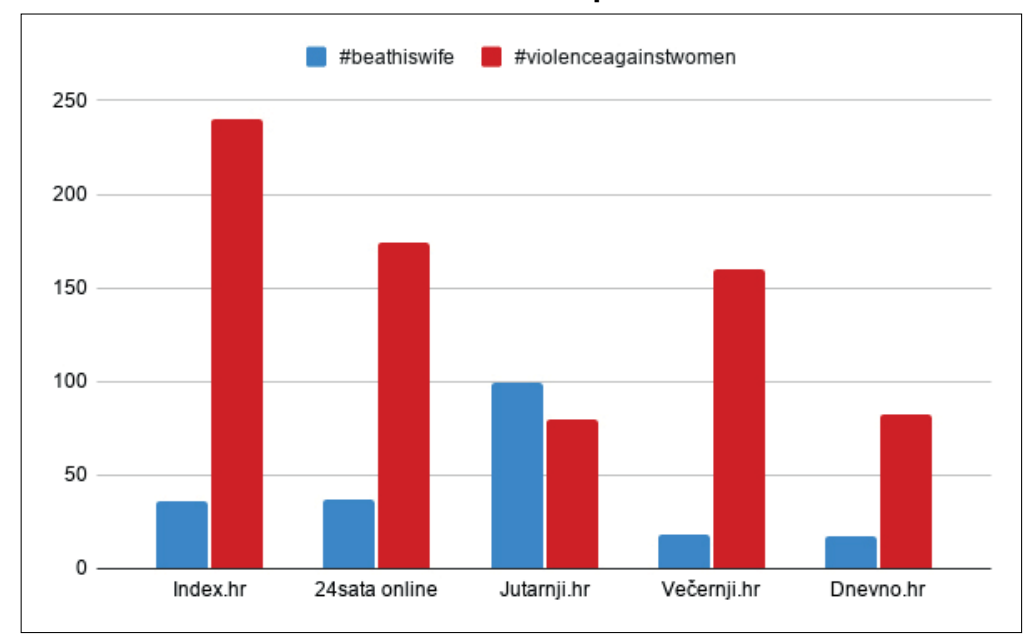

Source: Authors. Research period: April 2018 - October 2020.

We decided to conduct this research on selected articles published on five Croatian news portals, from which the first three (Index.hr, 24sata online and Jutarnji online) are the most popular according to Reuters Digital News Report (2020). ${ }^{1}$ Since two of them advocate and promote liberal values (Index.hr and Jutarnji online), we decided to include another two (Večernji.hr and Dnevno. hr) which are the most popular among conservative news portals. Research unit is an article with its headings and subheadings. Research period is from April 2018 (when the Istanbul Convention was ratified in Croatia) to October 2020. We used keyword or hashtag search. Since different articles on domestic violence and violence against women were published under different labels, we decided to use the hashtags 'violence against women' and 'he has beaten up a woman'.

$1 \quad$ We excluded Dnevnik.hr and Net.hr, because they do not have a well-optimized search engine that would meet the needs of this research. 
In total, 943 articles were detected $(\mathrm{N}$ for Index.hr = 276; $\mathrm{N}$ for 24sata online = 211; $\mathrm{N}$ for Jutarnji.hr = 179; $\mathrm{N}$ Vecernji.hr = 178; $\mathrm{N}$ for Dnevno.hr =99). The final sample is intentionally selected, due to diversity of language and narrative elements used while reporting on the issue. Final sample includes 276 articles published on Index.hr, 211 published on 24sata online, 179 on Jutarnji.hr, 178 on Vecernji.hr and 99 on Dnevno.hr.

\section{ANALYSIS}

\section{News Framing: Violence Against Women Is a Private Problem}

Framing gender-based violence as a violation of human rights and not as isolated incident is crucial for better understanding violence against women. Although violence against women is "a systemic attack, resulting from power relationships and domination that affects society as a whole" (Impe, 2019: 110), in articles we intentionally selected it is presented as a private problem of the family in which the violence has happened or a personal responsibility of a victim.

Večernji.hr reported:

Chaos at the wedding reception: drunk man hits a woman, his friends say he never drinks, and he is not an aggressive type (Večernji.hr, 29.4.2019).

This headline and its statements, which are later repeated in the text, are clearly in opposition of the event that occurred at the wedding reception. There is a statement from the friend of the drunk man, who says that "He probably gave himself little freedom at the wedding". They fail to recognise that "giving yourself a little freedom' does not mean a person can commit a violent crime. This kind of reporting normalises violence while being under the influence of alcohol and it defends toxic behaviours. It reflects the dominant stereotype that the only way men can loosen up during celebrations is alcohol and that this kind of behaviour will be tolerated, although it is 'normally' understood as bad. This sends a message that the victim's experience is not important because the perpetrator 'gave himself little freedom' and it is not to be taken seriously because it is not how the perpetrator usually behaves.

In another example, also from Večernji.hr, the story is titled "Because of violence in the school she gained weight, and then she lost $50 \mathrm{~kg}$. Now she motivates other women" (Večernji.hr, 13.10.2020). This report presents violence and bullying by one's peers as motivation to lose weight and fit into the beauty standard of 'petite, blond woman'. They fail to explain the context of the story and, instead of explaining violence among teenagers and educating the audience about how damaging peer pressure can be, journalist decided to focus only on her weight loss. This sends a dangerous message that a person can escape violence by being skinny and conventionally pretty. Trying to lose weight only to please others creates a harmful pattern of behaviour and can lead to developing more serious health conditions. This kind of reporting is extremely damaging and can 
have serious consequences for self-esteem and mental health of more sensitive, especially young readers. Moreover, Večernji.hr did not address violent behaviour and pointed it as a social problem. Framing this kind of story as inspirational, motivational and at the end, a private problem of the victim, fails to recognize peer pressure and violence as a systematic social problem among teenagers which needs to be addressed.

Reporters of 24sata.hr also show little recognition of violence against women as structural or power-related problem. In their coverage of the divorce of famous actors, Johnny Depp and Amber Heard, they refer to violence in their marriage as "bringing out the dirty laundry" (24sata.hr, 10.7.2020). Calling domestic violence 'dirty laundry' is not an adequate term because it diminishes suffering of the survivors and trivialises domestic violence. With this story, 24sata.hr frames domestic violence as a private problem, which is best to keep between the partners, away from the public eye. By framing domestic violence as a private problem and by labelling this issue as 'dirty laundry', the media discourage the readers who are maybe thinking about reporting their abusers to the officials. This indicates that domestic violence brings shame to the survivor since it will be discussed among other people, among family, relatives, neighbours, or friends. It indicates judgement of the society.

In selected articles violence against women is mostly framed as personal or marital problem. This shows a lack of understanding from journalists and editors and sends harmful messages to the victims that they are alone in their problems.

\section{Unfaithful Wives and Prostitutes Simply Deserved To Be Punished}

To protect survivor's privacy, it is recommended to use neutral addressing, like 'a woman'. However, to address the problem not as an isolated incident it is important sometimes to mention survivor's profession, just to point out that it happened to women of all professions: to managers, teachers, pilots, etc. But it is common that journalists mention a woman's profession only when they find it will attract more readers. An analysed article titled 'The tycoon's son killed a porn actress and tortured another woman for four days' (Index.hr, 18.09.2018) emphasizes the profession of the killed woman, mentioning she was working in porn industry, but does not write about the profession of the tortured woman. They simply name her 'the other woman'. This way of describing the victims is very problematic in two ways. Firstly, by mentioning she was a porn actress, Index.hr intentionally brings the controversy and sensationalism in the story about violent crimes with a clear intention to attract more readers. By connecting violence and the porn industry, Index.hr brings their readers the intrigue and dramatic plots inherent in television shows. This has farreaching consequences for the perpetuation of the stigma that accompanies porn industry actresses and the perception of their problems as something they themselves deserve because they are engaged in this type of work. Secondly, the tortured woman was not mentioned by any characteristics just because there is nothing sensational about her. 
Another representation category which was found in analysed articles was the category of 'unfaithful woman/wife', where the media emphasized that the violence happened because of the woman's infidelity. An example is article "Chaos on the island of Ugljan: A jealous husband interred into the house of a wife's lover and made a mess: He demolished furniture with an ax, hitting a woman on the head" (Jutarnji.hr, 27.02.2020). The title highlights the information that the wife had a lover, and that the husband committed the act of violence out of jealousy and anger. This finds excuses for the perpetrator from the beginning, and the blame for the violence is partly shifted to the woman. However, the text states that the woman was already living with her lover at the time of the violent act, which means that this was not news to the perpetrator and that he committed the violence rationally and not out of affect, as stated in the headline, which reads that perpetrator's mind was clouded by anger. This way of reporting is extremely harmful because it puts in the foreground the information that the woman was the one who had a lover and portrays her as the seductress and an infidel. Written like that, the article suggests that the husband was simply jealous. The whole narrative of the text, from emphasizing the love affair and 'clouding of the mind', leads the reader to think that the abuser is not entirely to blame for his act, and moreover it suggests to readers to even feel sorry for him. For Jutarnji.hr jealousy is an excuse for 'making a mess', for breaking into the house without permission, for cutting furniture, physically attacking another man and then the woman. Jutarnji.hr describes how a man broke into the house of a lover and found his wife there which contradicts the information they provided earlier in the text, that she has already lived with her lover, which means that she has already left her violent husband. The storyline is intentionally modified to bring more drama between the protagonists, and to share responsibility between the abuser and the victim.

Večernji.hr writes:

He found his woman with her lover, so he beat her up: 'He hit her with the doorframe' (Večernji.hr, 14.05.2020).

The title emphasizes that it was the woman who committed the fraud, so she probably deserved what happened to her. The way of reporting on this event has a frivolous tone, and at the beginning of the article the author presents the man's defence by quoting his statement that he 'committed the violence in affection'. Večernji.hr continues "That evening, he found his wife in his own house in bed with a lover who managed to escape through the window and passed without serious consequences. But the unfaithful wife was badly hurt". Her infidelity and the fact that she cheated on her husband in their house is emphasized five times through the text which shifts the blame on the wife, while reducing the husband's responsibility for his violent behaviour. Reporting about the lover who escaped through the window gives the article some comic elements, almost reality TV worthy, and provokes readers' interest towards the victim's sexual past. Writing about the wife's sexual past indicates judgement of the audience and partially shifts the blame to her. This way of reporting is harmful because it perpetuates 
social stereotypes about an unfaithful seductive woman and a man who 'can't help himself' and becomes violent just because of anger and disappointment. Public support is present in the comment section, where readers write: 'She asked for it, I'm sad for the man' or the sarcastic comment: 'The man is guilty because the woman was a whore? Bravo!'

The same story was covered by another, more conservative news portal Dnevno.hr (Dnevno.hr, 14.5.2020). The author of the article emphasized four times through the article that the woman was unfaithful, writing that "the unfaithful woman got multiple injuries..." and repeating her unfaithfulness every time the crime was mentioned. On the other hand, the author decided to publish the husband's statement that he "did that in affect". With such kind of reporting Dnevno.hr leads readers towards judgement of blaming the wife for what happened to her. In the comment section a couple of comments support the man, like this one: "Wow, imagine that, he is guilty that he beat up an unfaithful wife. What would happen to a poor woman if she was in the Saudi Arabia, in Jordan or in Indonesia. They would shoot her for that". This kind of victimblaming is in direct opposition with IFJ recommendations and shows a toxic media environment which perpetuates stereotypes and defends the perpetrator.

\section{Firstly, She Is a Victim of Violent Man, and Later She Is a Victim of Blame and Shame}

Secondary victimization occurs every time the victim's actions are further questioned in the media and when the emphasis is placed on what he or she did to provoke the stated behaviour. This is particularly inappropriate in cases of violence against women and domestic violence when victims are already traumatized by the committed act. At that point, the media must be extremely careful with their reporting, so they do not subject the victim to additional stigma, shame, fear, or insecurity. The already mentioned report of Jutarnji.hr from the island of Ugljan (Jutarnji.hr, 27.02.2020), where a husband broke into the house, demolished furniture, and hit the woman, can also be an example of secondary victimization. The survivor is portrayed as infidel and actions of the violent husband are partially excused by stating that she had a lover. By writing about the love life of the victim Jutarnji.hr indirectly questions if it was actually her fault that her husband reacted violently. By addressing the woman as a seductress and infidel, the blame for the violence is indirectly shifted to her, which later results in secondary victimization. In reporting on violence against women, these elements are often intertwined.

In another already mentioned article published on Večernji.hr (Večernji.hr, 14.05.2020) again the secondary victimization is made by blaming the wife for cheating on her husband, while forgiving the man because he "committed the violence in affection". Also, in Dnevno.hr in an article about the same story (Dnevno.hr, 14.5.2020) the victim is additionally traumatized each time her unfaithfulness is mentioned.

It is important to note that detailed reporting on the love life of a survivor, especially when she is a victim of a violent crime, is not only distasteful, but also 
contrary to all the rules of the journalistic profession and ethics. By stating facts that have little to do with the violent act, the media bring dramatic effect to the story and suggest that the survivor is in some way responsible for what happened to her. Such articles not only traumatize victims again, but also discourage other victims of violence who may be considering reporting their perpetrator. In addition, sending a message that the woman is to blame for what happened to her, diminishes public sensibility, and creates the image that the victim does not have the right to seek protection from the police or the court.

\section{Sensationalism Sells Good As it Is a 'Clickbait Catcher'}

Clickbait headlines boost advertising sale. According to the Reuters Digital News Report (2020), Index.hr is the most read news portal in Croatia. Although it represents liberal social values, it does not hesitate to be gender biased and highly sensational with an aim to attract as large audience as possible. They use bombastic, clickbait headlines and shocking details narrating on violence against women as in a crime novel. In such articles journalists write about violence very explicitly, for example: "Terrible confession of a woman from Russia: My husband cut off my hands with an ax" (Index.hr, 15.11.2018), "He imprisoned and beat his wife in Bakar: 'Die, may the cancer eat you'" (Index.hr, 26.02.2019), "A young man savagely beat his mother, strangled her and hit her on the head. He's not going to jail" (Index.hr, 13.02.2019) For such explicit depictions of violence, the Croatian Gender Equality Ombudsman says that they are used "as a hook for those who are not really interested in the suffering of victims or punishing the perpetrators, but perceive such reports as crime stories in sequels, as if they were not about real people" (Gender Equality Ombudsperson, 2014: 2). Such articles are written in the manner of a fiction text spiced with expressions that fall into the realm of horror films or crime series.

In the headlines of 24 sata.hr violence against women is described in detail, like crime stories with very explicit and frightening details. In March 2019, a journalist of 24sata.hr made a series of articles in which the abused woman described in detail the ways of her abuse. The titles are written sensationally and bring creepy details of abuse: "Did they $\mathrm{f}^{\star *} \mathrm{k}$ you? When I come back, you won't be there, you'll be dead..." (24sata.hr, 07.03.2019), "First he stabbed me in the leg with a fork, then he stabbed me in the knee" (24sata.hr, 06.03.2019) and "He beat me, took scissors and threatened: 'I'll take your scalp off'" (24sata.hr, 06.03.2019). Such shocking and sensational titles are simply not appropriate for the topic being written about and they dehumanize the victim.

The stated sensationalism of the 24sata.hr is also visible in the article from the protest for women's rights in South America, titled "She walked naked among soldiers at the protest after 'Women's Day'" (24sata.hr, 09.03.2020). One of the protesters stripped herself naked and painted her body with protest messages. The cover image with her naked buttocks is in close-up, which is completely contrary to the messages written in the text. This example shows that, although the text is written in a quality and informative way, the selected picture indicates that the naked female body is still used as bait for glances and cheap clicks. 
Jutarnji.hr also has sensationalist tendencies in reporting on this topic. Headlines such as "Women are beaten to the death or strangled" (Jutarnji.hr, 19.5.2020) or "He cut off the head of his Roma daughter with a sickle because of her love affair, which he did not support" (Jutarnji.hr, 28.05.2020) describe violence in a very explicit way and invite readers to click on the text to find out all the details.

Sensationalism used in the headlines is against professional journalistic standards. When reading about the horrific and unbelievable crimes happening to women, the reader may become alienated from the case being reported, thinking that it could never happen near her or him.

\section{CONCLUSION}

In contrary to UNESCO and IFJ recommendations that gender-based violence should be treated as a violation of human rights and not as an isolated incident, this analysis shows how violence against women is framed as a private problem (RQ1). Not one analysed article tried to represent violence against women as a problem of power relationships or as a complex social and cultural problem. In framing the story, authors of selected articles did not explain the context of the story.

The women represented in articles in this study were categorised in two main categories: unfaithful wives and prostitutes (RQ2). This kind of addressing women excuses the perpetrator from the violence act he made, while the blame for the violence is partly shifted to the woman. Further, treating a woman as a seductress and infidel, by connecting her infidelity with the husband's violent behaviour, the articles suggest that she intentionally provoked such behaviour (RQ3). Questioning the survivor's innocence, citing her sexual past and the partners she was with, leads to further degradation of the victim and provides a firmer framework within which the perpetrator can defend himself. Also, questioning the victim and citing details from her private life discourages readers who may be considering reporting gender-based violence which they experienced.

Women survivors are firstly victims of violent men, and additionally in the media they are presented as victims of blame and shame. Such secondary victimization occurs every time the victim's actions are further questioned in the media, narrating, and constructing the story on what she did to provoke the man's violent behaviour (Q4).

Selected Croatian online media write about violence very explicitly and they use bombastic, clickbait headlines and shocking details when narrating on violence against women (Q5). Such style is common for fiction in a crime novel. Short, superficial news stories with elements of sensationalism are not the professional, journalistic approach to address such important social problems as violence against women is.

Unfortunately, this research has proven that the Croatian online media is often interested in as many clicks as possible to make a profit, even when they report on someone else's misfortune. In selected articles journalists and editors 
do not follow the professional journalistic standards and recommendations from UNESCO (Impe, 2019) and IFJ (2014) on reporting about violence against women, and fundamental ethical principles are simply diminished by the possibility of earning money. Women-centred was by far the most common type of framing in this analysis, and women are framed as victims (Berns, 2004). By blaming the victim for provoking the perpetrator to do a violence act, the Croatian media perpetuate harmful social patterns by which the perpetrator is defended, and his actions are diminished (Cullen, O’Brien, and Corcoran, 2019). Victims are additionally traumatized and are not adequately protected in later legislative proceedings because their innocence is constantly questioned through the media (Yates, 2020). Also, by explicitly writing about the sexual past of victims of violence, it is once again proven that sex, unfortunately, sells, although it is based on violence.

Only continuous, thorough, and systematic education on reporting about women's and human rights, as well as on ethical reporting, can make journalists and editors fulfilling their professional tasks. The harmful practice of using tasteless clickbait should become irrelevant for journalistic reporting.

Viktorija Car (viktorija.car@fpzg.hr) holds a $\mathrm{PhD}$ in Media and Communications (2009) from the University of Ljubljana, Slovenia. She is Associate Professor at the University of Zagreb, Croatia and a Research Fellow of the Social Science Research Center at Mississippi State University, USA. In the focus of her research are visual media, media narratives, media and gender studies, media and human rights, and public service media. She is the founding Editor-

Barbara Ravbar (barbara.ravbar17@gmail. com) holds MA in Journalism (2019). She is a TV journalist at Televizija Zapad, Croatia. Her main research interests are media and gender studies, human rights, and minority studies. For her MA thesis research, she focused on an analysis of media coverage of the Istanbul Convention in the context of reporting on women's rights. She participated in The Balkan
in-Chief of the Medijske studije journal (20102017; <https://hrcak.srce.hr/medijske-studije>). She was a MC member of the COST Action IS0906: Transforming Audiences, Transforming Societies (2010-2014). She worked as a journalist and a screenwriter for the Croatian Public Service Television HRT (1998-2002) and was a member of the HRT Program Council (20112012). Her bibliography is available on $<\mathrm{http} / / /$ bib.irb.hr/lista-radova?autor=277195>.

Bridges project, which focused on covering stories about the refugee crisis in the Balkans. She won the 2nd prize for a multimedia project about Syrian refugees (2017), and Special Rector's prize for her work in student newspapers Global (2015). She was nominated in the finale for the 8th Annual Award for journalistic work that promotes the values of education (2021). 


\section{References}

Banks, Miranda (2018). "Production Studies". Feminist Media Histories, 4(2), pp. 157161.

Berns, Nancy (2004). Framing the Victim: Domestic Violence, Media, and Social Problems. New York: Aldine de Gruyter.

Calogero, Rachel M. (2004). "A Test of Objectification Theory: The Effect of The Male Gaze on Appearance Concerns in College Women". Psychology of Women Quarterly, 28(1), pp. 16-21. DOI: <10.1111/j.14716402.2004.00118.x>.

Car, Viktorija (2015). "Medijski diskursi". In: Car, Viktorija (ed.). Mi i oni kroz medijske naočale: Medijski diskursi u Bosni i Hercegovini, Hrvatskoj $i$ Srbiji. Zagreb-Beograd-Sarajevo: Kuća ljudskih prava Zagreb, Kuća ljudskih prava i demokratije Beograd, PRAVA ZA SVE, pp. 6-14.

Car, Viktorija and Osmančević, Leali (2016). "Televizijski narativi - pričam ti priču". Sarajevo Social Science Review / Sarajevski žurnal za društvena pitanja, 5(1-2), pp. 7-27.

Carlyle, Kellie E.; Orr, Caroline; Savage, Matthew W., and Babin, Elizabeth A. (2014). "News Coverage of Intimate Partner Violence: Impact on Prosocial Responses". Media Psychology, 17(4), pp. 451-471. DOI: $<10.1080 / 15213269.2014 .931812>$.

Carter, Cynthia; Steiner, Linda, and McLaughlin, Lisa (2013). The Routledge Companion to Media and Gender. London: Routledge.

Cuklanz, Lisa M. (2013). "Mass Media Representation of Gendered violence". In: Carter, Cynthia; Steiner, Linda, and McLaughlin, Lisa (eds.). The Routledge Companion to Media and Gender. London; New York: Routledge, pp. 32-41.

Cullen, Pauline; O'Brien, Anne, and Corcoran, Mary (2019). Reporting on Domestic Violence in the Irish Media: An Exploratory Study of Journalists' Perceptions and Practices. Media, Culture \& Society 00(0), pp. 1-17. DOI: <https:// doi.org/10.1177/0163443718823141>.
Dijk, Teun A. van (2001). "Critical Discourse Analysis". In: Schiffrin, Deborah; Tannen, Deborah, and Hamilton, Heidi E. (eds.). The Handbook of Discourse Analysis. Padstow: Blackwell Publishers, pp. 352-371.

Fairclough, Norman (2010). Critical Discourse Analysis: The Critical Study of Language. 2nd edition. London; New York: Routledge.

Gamson, William A. and Modigliani, Andre (1987). "The Changing Culture of Affirmative Action". Research in Political Sociology, (3), pp. 137-177.

Gender Equality Ombudsperson (2014). Report on the Work of the Gender Equality Ombudsperson Work Report for the year 2013. Zagreb: Republic of Croatia.

Gillespie, Marie (2006). "Narrative Analysis". In: Gillespie, Marie and Toynbee, Jason (eds.). Analysing Media Texts. New York: Open University Press, pp. 79-117.

Haskell, Molly ([1974] 1987). From Reverence to Rape: The Treatment of Women in the Movies. 2nd edition. Chicago: University of Chicago Press.

Hay, Iain and Israel, Mark (2001). “’Newsmaking Geography': Communicating Geography Through the Media". Applied Geography, 2001(21), pp. 107-125.

Hermes, Joke (2012). Žene $i$ novinari/ novinarke imaju prednost. Zagreb: Ured za ravnopravnost spolova Vlade $\mathrm{RH}$.

IFJ (2014). IFJ Guidelines for Reporting on Violence Against Women. International Federation of Journalists. Available at: <https:// www.ifj.org/fileadmin/user_upload/IFJ_ Guidelines_for_Reporting_on_Violence_ Against_Women_EN.pdf $>$. Accessed 21 January 2021.

Impe, Anne-Marie (2019). Reporting on $\mathrm{Vi}$ olence against Women and Girls: A Handbook for Journalists. Paris: UNESCO.

Kunczik, Michael and Zipfel, Astrid (1998). Uvod u publicističku znanost $i$ komunikologiju. Zagreb: Zaklada Friedrich Ebert. 
Lewis, Justin (1991). The Ideological Octopus: An Exploration of Television and its Audience. London: Routledge.

Morgan, Jenny and Politoff, Violeta (2012). Victorian Print Media Coverage of Violence Against Women. Available at <https:// www.vichealth.vic.gov.au/-/media/Resource Centre/PublicationsandResources/PVAW/ PVAW-in-the-media/VH_PVAW-in-Media Summary_web.pdf?la=en\&hash $=4$ FF39AE1A 6BFD026785E80E4461563E63CE49585>. Accessed 9 February 2021.

Mulvey, Laura (1975). "Visual Pleasure and Narrative Cinema". Screen, 16(3), pp. 6-18. DOI: <10.1093/screen/16.3.6>.

Pan, Zhongdang and Kosicki, Gerald (1993). "Framing Analysis: An Approach to News Discourse". Political Communication, 10(1), pp. 55-75. DOI: $<10.1080 / 10584609.19$ 93.9962963>.

Reuters Digital News Report (2020). "Croatia". Available at: <https://www.digitalnewsreport.org/survey/2020/croatia-2020/>. Accessed 9 February 2021.

Sutherland, Georgina; McCormack, Angus; Easteal, Patricia; Holland, Kate, and Pirkis, Jane (2016). "Media Guidelines for the Responsible Reporting of Violence Against Women: A Review of Evidence and Issues". Australian Journalism Review, 38(1), pp. 5-17.

Tuchman, Gaye (1978). "The Symbolic Annihilation of Women by the Mass Media". In: Tuchman, Gaye and Daniels, Arlene Kaplan (eds.). Hearth and Home: Images of Women in the Mass Media. New York: Oxford University Press, pp. 3-37.

Walby, Sylvia (2005). Violence Against Women and the Millennium Development Goals. New York: United Nations, Division for the Advancement of Women.

Wodak, Ruth and Busch, Brigitta (2004). "Approaches to Media Texts". In: Downing, John D. H.; McQuail, Denis; Schlesinger, Philip, and Wartella, Ellen A. (eds.). The SAGE Handbook of Media Studies. Thousand Oaks; London; New Delhi: SAGE, pp. 105-122.
Yates, Sophie (2020). "Gender, Context and Constraint: Framing Family Violence in Victoria". Women's Studies International Forum, 78, 102321, pp. 1-11. DOI: <10.1016/j. wsif.2019.102321>.

\section{Cited analysed articles}

\section{4.sata.hr}

Bilešić, Romana (2019). "Jesu li je j**kli? Kad se vratim, tebe neće biti, bit ćeš mrtva..." ["Did they $\mathrm{f}^{\star *} \mathrm{k}$ her? When I come back, you will not be here, you will be dead..."] 07.03.2019. Available at: <https://www.24sata.hr/news/ jesu-te-j-li-kad-se-vratim-tebe-nece-biti-bitces-mrtva-617800>. Accessed 14 November 2020.

-. (2019). "Prvo mi je zabio vilicu u nogu, a zatim mi zario nož u koljeno" [He first stabbed me in the leg with a fork, then stabbed me in the knee"] 07.03.2019. Available at: <https://www.24sata.hr/news/jasam-htjela-pobjeci-od-njega-i-tad-mi-je-zabiovilicu-u-nogu-617767>. Accessed 14 November 2020 .

—. (2019). "Pretukao me, uzeo je škare i zaprijetio: 'Skalp ću ti skinuti" ["He beat me, took scissors and threatened: 'I'll take your scalp off'"] 06.03.2019. Available at: <https://www.24sata.hr/news/prvo-mepretukao-nogama-pa-uzeo-skare-i-skroz-meosisao-617739>. Accessed 14 November 2020.

HINA (2020). "Gola šetala među vojnicima na prosvjedu nakon 'Dana žena" ["She walked naked among soldiers at the protest after 'Women's Day'”] 09.03.2020. Available at: <https://www.24sata.hr/news/gola-setalamedu-vojnicima-na-prosvjedu-nakon-danazena-680231>. Accessed 14 November 2020.

Pušić, Bruno (2020). "Amber je Deppu odsjekla dio prsta, on joj ime napisao krvlju" ["Amber cut off part of Depp's finger, he wrote her name in blood"] 10.7.2020. Available at: <https:// www.24sata.hr/show/amber-je-deppu-odsjekladio-prsta-on-joj-ime-napisao-krvlju-704980>. Accessed 14 November 2020. 


\section{Dnevno.hr}

Dnevno.hr. (2020). "Pretukao nevjernu suprugu štokom od vrata! Sud ga proglasio krivim" ["He beat his unfaithful wife with a door frame! The court found him guilty"] 14.05.2020. Available at: <https:// www.dnevno.hr/vijesti/pretukao-nevjernusuprugu-stokom-od-vrata-sud-ga-proglasiokrivim-1468271/>. Accessed 14 November 2020.

\section{Index.hr}

J.Mi. (2018). "Tajkunov sin ubio porno glumicu, a drugu je ženu mučio četiri dana" ["The tycoon's son killed a porn actress and tortured another woman for four days"] 18.09.2018. Available at: <https://www. index.hr/magazin/clanak/tajkunov-sin-ubioporno-glumicu-a-drugu-je-zenu-mucio-cetiridana/2024636.aspx>. Accessed 14 November 2020 .

R.I. (2019). "Mladić divljački pretukao majku, davio je i udarao po glavi. Ne ide u zatvor" ["The young man savagely beat his mother, strangled her and hit her on the head. He's not going to jail"] 13.02.2019. Available at: <https://www.index.hr/vijesti/clanak/mladicdivljacki-pretukao-majku-davio-je-i-udaraopo-glavi-ne-ide-u-zatvor/2063788.aspx>. Accessed 14 November 2020.

-. (2019). "Zatočio i pretukao ženu kod Rijeke: 'Umri, dabogda te rak pojeo'. Sudi mu se" ["He imprisoned and beat a woman near Rijeka: 'Die, may the cancer eat you'. He is on trial"] 26.02.2019. Available at: <https://www. index.hr/vijesti/clanak/zatocio-i-pretukaozenu-kod-rijeke-umri-dabogda-te-rak-pojeosudi-mu-se/2066994.aspx?index_ref=read_ more_d>. Accessed 14 November 2020.

T.J.D. (2018). "Strašna ispovijest žene iz Rusije: Muž mi je odsjekao ruke sjekirom" ["He imprisoned and beat a woman near Rijeka: "Terrible confession of a woman from Russia: My husband cut off my hands with an $\left.\mathrm{ax}^{\prime \prime}\right]$ 15.11.2018. Available at: <https://www.index.hr/vijesti/clanak/strasnaispovijest-zene-iz-rusije-muz-mi-je-odsjekaoruke-sjekirom/2042685.aspx>. Accessed 14 November 2020.

\section{Jutarnji.hr}

Zadarski.hr. (2020). "Kaos na otoku Ugljanu: ljubomorni muž upao u kuću suprugina ljubavnika i napravio rusvaj sjekirom demolirao namještaj, ženu izudarao po glavi" ["Chaos on the island of Ugljan: A jealous husband interred into the house of a wife's lover and made a mess: He demolished furniture with an ax, hitting a woman on the head"] 27.02.2020. Available at: <https://www.jutarnji.hr/vijesti/ crna-kronika/kaos-na-otoku-ugljanu-ljubomorni-muz-upao-u-kucu-suprugina-ljubavnika-i-napravio-rusvaj-sjekirom-demoliraonamjestaj-zenu-izudarao-po-glavi-10026565>. Accessed 14 November 2020.

HINA (2020). "Žene bivaju pretučene do smrti ili zadavljene. U Argentini tijekom karantene ubijeno najviše žena $\mathrm{u}$ zadnjih 10 godina" ["Women beaten to death or consolidated: Most women killed in quarantine in Argentina in 10 years"] 19.05.2020. Available at: <https://www.jutarnji.hr/vijesti/svijet/ zene-bivaju-pretucene-do-smrti-ili-zadavljene-u-argentini-tijekom-karantene-ubijenonajvise-zena-u-zadnjih-10-godina-10320700>. Accessed 14 November 2020.

Jutarnji.hr. (2020). "Srpom odrubio glavu svojoj kćeri romini zbog njezine ljubavne veze koju nije podržavao cijeli svijet zgrožen stravičnim zločinom u iranu" ["He beheaded his daughter Romina with a sickle because of her love affair, which he did not approve. The whole world Is Horrified by the horrific crime in Iran"] 28.05.2020. Available at: <https://www.jutarnji.hr/vijesti/ svijet/srpom-odrubio-glavu-svojoj-kceriromini-zbog-njezine-ljubavne-veze-koju-nijepodrzavao-cijeli-svijet-zgrozen-stravicnimzlocinom-u-iranu-10347883>. Accessed 14 November 2020. 


\section{Večernji.hr}

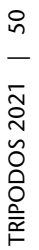

Hajduk, Tina (2020). “Zbog vršnjačkog nasilja drastično se udebljala, a onda je skinula čak 50 kilograma: "Sada motiviram druge žene" [She gained a lot of weight due to peer violence, and then she lost as much as 50 kilograms: 'Now I motivate other women'] 13.10.2020. Available at: <https://www.vecernji.hr/ lifestyle/zbog-vrsnjackog-nasilja-drasticno-seudebljala-a-onda-je-skinula-cak-50-kilogramasada-motiviram-druge-zene-1438101>. Accessed 14 November 2020.

Mihaljević, Robert (2020). "Ženu zatekao s ljubavnikom pa je premlatio: 'Udarao ju je drvenim okvirom vrata" ["He found his woman with her lover and beat her: 'He hit her with a wooden door frame"] 14.05.2020. Available at: <https://www.vecernji.hr/vijesti/ zenu-zatekao-s-ljubavnikom-pa-ju-premlatioudarao-ju-drvenim-okvirom-vrata-1402197>. Accessed 14 November 2020.

Večernji.hr. (2019). "Kaos na svadbi: Pijan udario ženu, a prijatelji kažu da nikad ne pije i da nije agresivan" ["Chaos at a wedding: Drunk man hits a woman, and friends say he never drinks and is not aggressive"] 29.04.2019. Available at: <https:// www.vecernji.hr/vijesti/predsjednik-hvidrevinkovci-na-kcerinoj-svadbi-pijan-udariosuprugu-i-zavrsio-u-pritvoru-1316104>. Accessed 14 November 2020. 